Article

\title{
Environmentalism and Polish Coal Mining: A Multilevel Study
}

\author{
Piotr Zientara ${ }^{1}$, Anna Zamojska ${ }^{2}$ (D), Grzegorz Maciejewski ${ }^{3, *}$ (I) and \\ Anna Maria Nikodemska-Wołowik ${ }^{1}$ \\ 1 Institute of International Business, Faculty of Economics, University of Gdansk, 81-824 Sopot, Poland; \\ zientara@fest.pl (P.Z.); amnw@ug.edu.pl (A.M.N.-W.) \\ 2 Department of Econometrics, Faculty of Management, University of Gdansk, 81-824 Sopot, Poland; \\ a.zamojska@ug.edu.pl \\ 3 Department of Market and Consumption, Faculty of Economics, University of Economics in Katowice, \\ 40-287 Katowice, Poland \\ * Correspondence: grzegorz.maciejewski@ue.katowice.pl; Tel.: +48-501-615-720
}

Received: 6 May 2019; Accepted: 26 May 2019; Published: 31 May 2019

check for updates

\begin{abstract}
This paper, drawing on a questionnaire survey conducted among 587 coal miners from six coal mines, seeks to ascertain whether the Polish coal mining industry is committed to organizational greening and whether its employees behave in environmentally responsible ways. Specifically, it explores-by means of hierarchical linear modeling (HLM) - the direct effects of green organizational climates on miners' pro-environmental conduct at home and at work. We found that climates had a direct effect on employee behavior in and outside the workplace, and that personal environmental values were positively related to the latter variable. However, it has to be admitted that the actual engagement of coal miners in voluntary pro-environmental action at work was not very deep. Crucially, it turned out that, in two coal mines, there were strong green climates, while the rest were weak, which suggests differences in terms of commitment to organizational greening throughout the industry. The present paper explores the significance of the results and highlights the applicability of our methodological approach to the study of employee involvement in organizational pro-environmental action.
\end{abstract}

Keywords: green climate; organizational greening; pro-environmental behavior; coal mining; Poland

\section{Introduction}

Pursuit of environmental sustainability depends, to a great degree, on ordinary peoples pro-environmental engagement. Certain societies have a well-deserved reputation for environmental friendliness. This holds particularly true of Scandinavians. By contrast, Poles are not known for their strong attachment to sustainability [1,2]. Poland does not fare particularly well in the Environmental Performance Index-it ranks 50th among 180 countries [3]. Moreover, reliance on coal for electricity generation explains why Poland is perceived as the greatest hindrance to the implementation of the Paris Agreement in the European Union (EU). Nonetheless, coal is likely to remain part of the energy mix in many countries, meaning that organizational greening should be a top priority for the entire industry, which, by extension, underscores the role of employee pro-environmental engagement. However, there are a lot of stereotypes surrounding miners' attitudes towards environmentalism. They are often portrayed as tough guys who pay scant regard to environmental concerns. Likewise, there is a stigma attached to coal mines. Therefore, Poland offers a context particularly well-suited to ascertaining whether Polish mines are committed to organizational greening-as implied by the 
hypothesized existence of green organizational climates-and to analyze their direct effects on miners' pro-environmental behaviors at home and at work.

It is true that the psychological mechanism that underlies individual engagement in pro-environmental behavior has been the subject of numerous studies. Indeed, an array of research has focused on (factors which may affect) one's propensity to act in environmentally friendly ways at home (e.g., [4-11]), on holiday (e.g., [12]), and in the workplace (e.g., [13-17]). The environmental values-behavior gap has also become the subject of much debate (e.g., [18]). However, most of the above studies, unlike this one, are based on individual (non-aggregated) perceptions and draw on methodologies other than multi-level analysis and hierarchical linear modeling. Crucially, they do not rely on data collected in coal mining. Thus, this study, while expanding the scope and the method of analysis, improves our knowledge of the socio-psychological processes that are at the heart of interaction between man, industry, and the environment.

\section{Theoretical Background and Hypotheses}

\subsection{Individual Pro-Environmental Behavior}

Surveys of public opinion point to a growing environmental awareness across the world [19]. This reflects the assumption that "people in general do not wish to harm the environment" [20] (p. 27). The problem is that, even though most individuals want to live in an unspoiled environment [21], only some of them behave in environmentally responsible ways [22]. That is because people do not want to be bothered with extra effort, are unwilling to modify their lifestyle and relinquish their high standard of living, or simply do not think that their individual action will have much of an impact in the overall scheme of things.

Therefore, the motivation behind exhibiting such behaviors is of great interest to environmentalists. The general consensus is that a green awareness lies at the core of pro-environmental engagement. It might be problematic to expect someone who does not have "a certain degree of environmental knowledge and awareness" [5] (p. 254) to act in a responsible way. It is fair to say, therefore, that those who realize that the environment is threatened might be more likely to segregate waste, recycle (or upcycle), buy green products, or commute by public transport than those who do not. However, the mechanism by which individuals engage in pro-environmental behaviors is far more complex.

Researchers have used different theoretical frameworks-namely, the norm-activation model (NAM), the theory of planned behavior (TPB), or the value-belief-norm theory (VBN)-to unpick this motivational mechanism. For example, Arvola et al. [23] used the NAM, Oreg and Katz-Gerro [24] drew both on the TPB and the VBN, while Stern, Dietz, Abel, Guagnano, and Kalof [25] adopted the VBN. Specifically, the NAM states that behavior is predicted by one's personal norms [26]. The TPB holds that behavior is determined by intentions, which themselves are a function of attitudes, subjective norms, and perceived behavioral control. The VBN suggests that an individual who holds certain values and believes that those values are threatened experiences an obligation to act in defense of those values. The VBN suggests that individuals feel obligated to defend their values when they believe that those values are under threat.

\subsection{The Role of Values}

Since values construe "what people believe to be fundamentally right or wrong" [27] (p. 41) and hence form "foundations for attitudes, which in turn, provide bases for action" [28] (p. 730), the strand of research that draws on the VBN seeks to ascertain whether environmental values indeed have a vital involvement in determining pro-environmental behavior (e.g., $[4,7,29,30])$. Most studies show that it is the case, although there is some evidence to the contrary [17,31]. Nevertheless, the problem is the existence of the environmental values-behavior gap or a disparity between a person's values and their actual deeds [18]. Thus, the fact that someone is notionally attached to environmental values does not necessarily have to translate into green conduct [32]. It follows that, even if one declares that they hold 
values aligned with sustainability, their actual engagement in pro-environmental action should not be taken for granted. This holds especially true of tourists.

Given the aforementioned considerations, should one be skeptical of the correlation observed between environmental values and green behavior? Enough empirical evidence has been collected to believe that one's values do determine their environmentally responsible conduct. Most studies adopting the VNB framework, including those focusing on consumer green behavior (e.g., [29]), support this, thereby upholding the validity of the theory.

Moreover, cognitive dissonance theory [33] holds that humans do not always behave in line with their values and beliefs, especially when this involves putting up with certain discomforts or making sacrifices. The implication is that the inconsistencies characterizing human behavior do not, as such, weaken the fundamental role of values. Put another way, the very fact that there is occasionally dissonance between one's values and one's deeds does not automatically imply that the former do not "guide individuals to function in a society" [34] (p. 5). Another problem is related to financial constraints. For instance, some motorists would like to buy an electric car, but, since these vehicles are still relatively expensive, they cannot afford it. In light of the abovementioned reasoning, the following hypothesis is proposed:

Hypothesis 1. There is a positive relationship between one's environmental values and their pro-environmental behavior at home.

\subsection{Individual Pro-Environmental Behavior at Work}

Most individuals who are in wage employment spend a chunk of their time at work, where they can contribute to the organizational pursuit of sustainability voluntarily or involuntarily [35]. Of greater importance to organizational greening are voluntary pro-environmental behaviors, which originate from employees' senses of citizenship. These voluntary, pro-environmental behaviors are known as organizational citizenship behavior for the environment (OCBE). It is defined as "discretionary acts by employees within the organization not rewarded or required that are directed toward environmental improvement" [14] (p. 246). Moreover, Boiral and Paillé [36] argue that OCBE can take three forms: eco-civic engagement, eco-initiatives, and eco-helping.

Yet, employee participation in OCBE is not unproblematic. For one thing, management cannot compel workers to engage in OCBE because "no company can mandate volunteerism" [37] (p. 93). For another, given that all extra-role behaviors, including OCBE, vie for both time and attention with employees' in-role tasks, many employees may be unable (or perhaps unwilling) to perform activities that go beyond their formal job responsibilities. Such an attitude is reinforced by job pressures and other related inconveniences-an issue of relevance to the coal mining industry. It follows that those employees who do decide to engage in OCBE must be strongly motivated to do so. Additionally, to follow the line of argumentation from the previous section, values might constitute a source of such extra motivation. This is in accordance with the implications of self-determination theory [38], which suggests that intrinsic factors, such as values, are strong motivational drivers. Crucially, values are a solid foundation of ethics [39], which are a powerful determinant of human behavior [40]. Thus, we posit that:

Hypothesis 2. There is a positive relationship between an employee's environmental values and their engagement in $O C B E$.

\subsection{The Role of the Work Environment}

Albeit to a great extent, one's behavior is driven by their personal values, the environment in which they function is likewise a determinant. Indeed, when it comes to the workplace reality, the consensus is that it is organizational factors that-in combination with individual characteristics-underpin the engagement of employees in extra-role, pro-environmental behaviors [17]. That thinking has solid 
theoretical foundations. Organismic integration theory, which describes the process through which individuals can become strongly motivated from external stimuli, implies that one's milieu can act as a source of motivation [41]. The theory of reasoned action holds that a direct experience with a given thing causes an individual to form beliefs about that thing. Crucially, when a person forms a belief about a given object, they automatically develop a positive or negative attitude towards that object. Since individuals hardly ever put into doubt the validity of their own senses, they tend to ascribe certainty to beliefs derived from their direct experiences.

Yet, apart from direct experiences, it is also observation of others that shapes people's beliefs and behaviors. This view is rooted in social learning theory, which affirms that learning is a cognitive process that is embedded in the social context and can come about via observation. The implication is that humans learn through observing the actions and the behaviors of others [42]. Furthermore, social identity theory postulates that, by modifying the self-identity or at least part of the self-concept that is acquired from the knowledge and the emotional attachment of an employee to group membership, an organization can change individuals' behaviors [43]. Social information processing theory states that the milieu in which people operate shapes their attitudes and behaviors because it provides clues as to what is socially acceptable and, by extension, as to what is expected of them [44].

All of this supports the concept of organizational climate, which Schneider and Reichers [45] define as a set of common perceptions concerning policies, practices, and procedures in which the organization supports. Climate research explores how employees' individual perceptions (aggregated to the group level) concerning the work environment "drive their behaviors and attitudes [ ... ]" [46] (p. 635). Employees make sense of their workplace reality by interpreting cues coming from it and then by sharing their perceptions with their colleagues. Therefore, what lies at the core of climate formation is the interactive sense-making process. Given the focus of this study, of special interest is a green organizational climate (GOC), which refers to the common perceptions of employees' towards the commitment of their organization to environmental sustainability [47]. In practice, these perceptions concern the way an organization goes about greening its operations (e.g., environmental policy, managerial pro-environmental conduct, green practices and measures, etc.). Hence, for example, when an organization provides its employees with environmental training, communicates its unswerving commitment to sustainability and, at the same time, introduces green practices, staff are likely to learn GOC.

It follows that climate formation is a complex process that is driven by several factors. Arguably, of special significance is the conduct and the views of middle managers, who usually act as supervisors. Unlike senior managers, middle managers are in constant touch with their subordinates, which renders the latter more receptive to their opinions and suggestions [48]. Furthermore, since supervisors are perceived by employees as core agents of the organization [49], their views are interpreted as representing the views of the organization itself. Accordingly, in order to foster GOC, middle managers should explain to their charges the sense of organizational greening and, ideally, set an example and inspire them to behave in an environmentally responsible way.

What it all comes down to is the assumption that a climate, in effect, acts normatively, indicating to employees what behavioral patterns their organization expects of them. Thus, it is justified to presume that whenever workers experience GOC, they may be more likely to employ OCBE. Crucially, evidence (albeit from the hotel industry) GOC suggests that had direct effects on employee voluntary pro-environmental behavior in the workplace [47]. Hence, theoretical and empirical foundations do exist that support the following hypothesis:

Hypothesis 3. GOC has a direct effect on $O C B E$.

The above discussion implies that much of what happens to individuals at work influences their attitudes and behaviors [45]. Yet, because people tend to internalize values and, by extension, behavioral patterns [50], this influence may well extend beyond the workplace to other spheres of life. 
Therefore, when operating in GOC, employees are not only more likely to engage in OCBE but also more likely to transpose such conduct to their home environments, thereby acting responsibly outside the workplace as well. Put another way, when employees leave work, where they are exposed to GOC - thanks to which they internalize environmentally friendly behaviors - they may be more likely to behave responsibly once back home. It should also be noted that this internalization of behavior is usually undergirded by a sense of pride felt by an individual after engaging in a particular act, or, even more frequently, by a sense of shame after failing to do so. Accordingly, the following hypothesis is proposed:

Hypothesis 4. GOC has a direct effect on pro-environmental behavior at home.

Figure 1 presents our conceptual model.

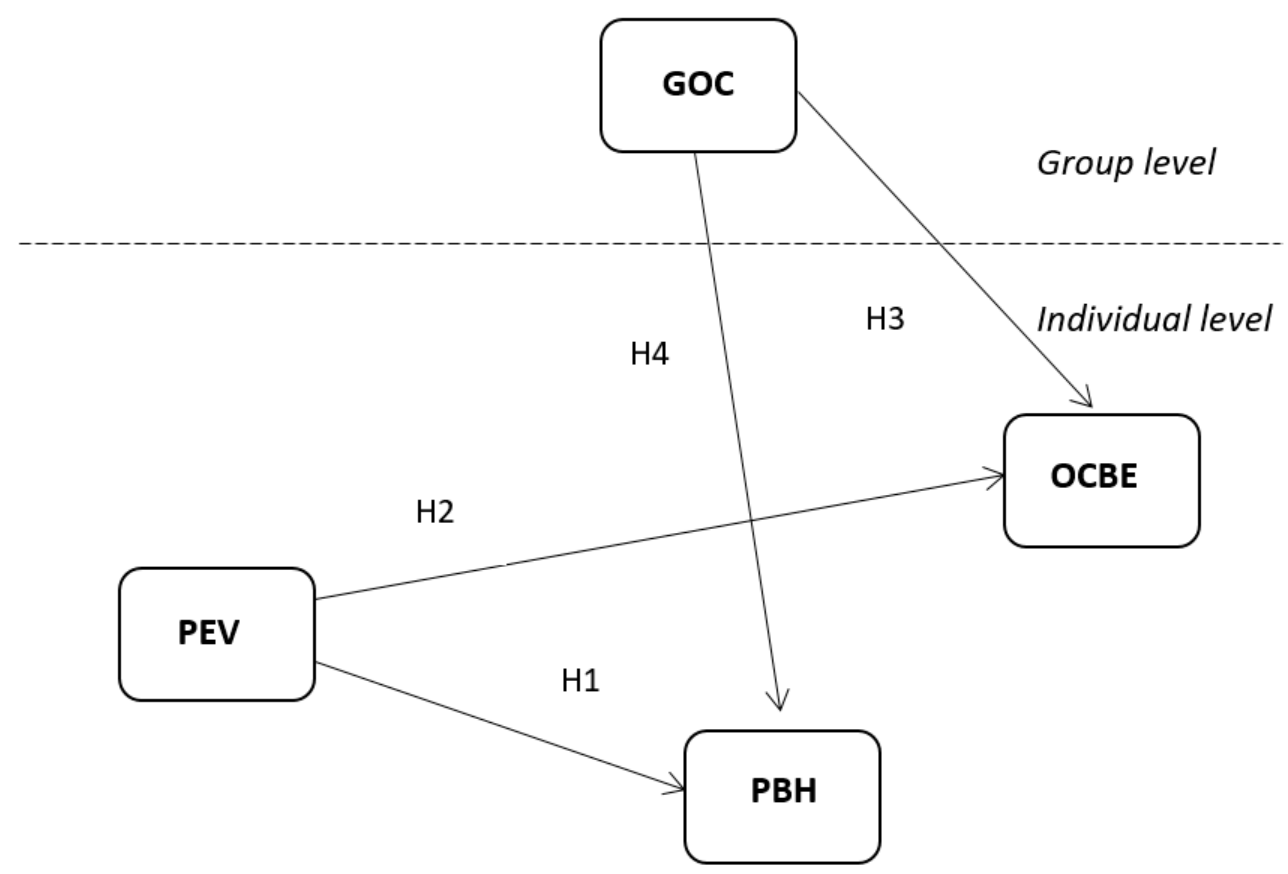

Figure 1. The conceptual model. Data source: Own study. GOC: green organisational climate. OCBE: organisational citizenship behaviour for the environment. PEV: personal environmental values. $\mathrm{PBH}$ : pro-environmental behaviour at home.

\section{Context of the Study}

Poland's mining industry is made up of six holdings, which operate 19 mines: (a) Jastrzęska Spółka Wẹglowa (four coal mines); (b) Polska Grupa Górnicza (nine); (c) Tauron Wydobycie (three); Przedsiębiorstwo Górnicze Silesia (one); (d) Lubelski Węgiel Bogdanka S.A. (one); (e) Wẹglokoks (one). The fact that it produces coal—the dirtiest fossil fuel-that is then burned to generate electricity hardly advances environmental sustainability. In this way, the industry indirectly contributes to climate change and smog hanging over Polish cities. However, what is often overlooked is that green measures are being taken to reduce the industry's (direct) environmental footprint. There are two reasons for this. First, there is a growing realization of the need to engage in organizational greening; both managements and unions seem to have realized that, if their industry is to have any future, it needs to be as clean and environmentally neutral as possible. Second, under pressure from the EU, the stricter enforcement of environmental regulations has, of late, become a reality in coal mining.

At the same time, changes in attitudes towards the environment have been displayed among ordinary Poles. An opinion poll found that more than $80 \%$ of respondents understood the terms "climate change" and "renewable sources of energy", and that more than 70\% segregated household 
waste [51] (p. 50). Thus, more and more Poles are aware that environmental concerns need to be addressed not only by businesses but also by ordinary people such as themselves. This is reinforced, as just mentioned, by a well-publicized issue of air pollution. When it comes to air quality, regarded as the leading environmental threat to public health, Poland is a particularly low scorer among the EU countries [3].

\section{Method}

\subsection{Sample and Data Collection}

A 23-item paper-and-pencil questionnaire was used to collect data. In 2017, we randomly selected six coal mines and contacted their respective trade-union officials, asking them to help us conduct the survey. Altogether, 608 responses were gathered, of which 21 were considered incomplete. Therefore, for further analysis, 587 responses were used. Respondents were asked to rate each item on a five-point Likert scale, ranging from 1 (strongly disagree) to 5 (strongly agree). Our sample was made up of sets of 50 to 163 employees per group (e.g., mine). The sample was $82 \%$ male. An average respondent was 39 years old. Eighty-four percent had a high-school or a vocational-school diploma, and the rest had a university education.

\subsection{Measures}

OCBE was measured with five items [52] $(\alpha=0.75)$. GOC was measured with seven items [47] $(\alpha=0.87)$. Personal environmental values (PEV) were measured with six items, with most of them taken from Stern et al. [25] $(\alpha=0.69)$. Finally, pro-environmental behavior at home (PBH) was measured with five items $(\alpha=0.60)[4,21]$. Given that the cut-off point for Cronbach's alpha is 0.70 , there were two outliers (see Table 1). However, since reliability scores that fall between 0.60 and 0.70 serve as the lower limit of acceptability [53], we therefore resolved to consider them. The Appendix A displays the full list of used items concerning the research instrument.

We described GOC by using a direct consensus model [54] whereby participants reported on their own perceptions. To create a measure of the collective construct (individual coal mine was identified as the appropriate level of aggregation), we then aggregated the reported perceptions with those of others' perceptions. The instrument employed to measure GOC implemented an individual referent as opposed to a referent-shift approach. Thus, climate ratings with an individual referent denote a psychological climate that, when aggregated to the organizational level, constitutes an organizational-level construct-that is, an organizational climate (but not an organizational collective climate).

Table 1. Means, standard deviations, Cronbach's alphas, and Spearman correlations of variables.

\begin{tabular}{ccccc}
\hline Variable & OCBE & PBH & PEV & GOC \\
\hline OCBE & $(0.74)$ & & & \\
PBH & $0.536^{*}$ & $(0.60)$ & & \\
PEV & $0.528^{*}$ & $0.496^{*}$ & $(0.69)$ & \\
GOC & $0.592^{*}$ & $0.513^{*}$ & $0.518^{*}$ & $(0.87)$ \\
Mean & 3.647 & 3.660 & 3.614 & 3.232 \\
SD & 0.709 & 0.692 & 0.685 & 0.819
\end{tabular}

${ }^{*} p<0.05$. Note: $\mathbf{n}=587, \mathrm{M}-$ means, SD—standard deviation, scale reliability in bold along diagonal. Data source: collected by this research.

\subsection{Procedure}

We followed Baron and Kenny's [55] procedure. At the outset, we estimated a level-one null model with no independent level-one variables. We then estimated a random coefficient regression model and an intercepts-as-outcomes model to test the direct effects of GOC (see Tables 2 and 3, and Figure 2). We controlled for gender, age, and education. Only age turned out to have a significant effect on $\mathrm{PBH}$. 
Table 2. Results of hierarchical linear modeling for OCBE.

\begin{tabular}{cccc}
\hline Variables & Null Model & Individual-Level Predictors & Intercepts-As-Outcomes Model \\
\hline & & Level 1 \\
\hline Intercept & $3.65^{*}(0.04)$ & $3.65^{*}\left(0.06^{* *}\right)$ & $3.65^{*}(0.05)$ \\
PEV & & $0.62^{*}\left(0.21^{*}\right)$ & $0.62^{*}\left(0.20^{*}\right)$ \\
\hline & Control variables \\
\hline Gender & 0.01 & 0.01 \\
Age & 0.01 & 0.01 \\
Education & 0.06 & 0.06 \\
\hline & & Cross level \\
\hline GOC & & 0.326 & $0.06^{* *}$ \\
Level-1 residual variance & 0.501 & 1045.46 & 0.324 \\
Model deviance & 1265.87 & & 1040.92 \\
\hline
\end{tabular}

Note: $\mathrm{n}=587$ (employee); $\mathrm{n}=6$ (coal mine). Entries are estimates of the fixed effects $\left(\gamma_{\mathrm{s}}\right)$ with robust standard errors. Estimations of the random variance components $\left(\tau_{\mathrm{s}}\right)$ are in parentheses. The $\tau_{\mathrm{s}}$ for the intercepts also represent the between-mine variance in GOC. ${ }^{*} p<0.05 ;{ }^{* *} p<0.10$. Data source: collected by this research.

Table 3. Results of hierarchical linear modeling for PBH.

\begin{tabular}{cccc}
\hline Variables & Null Model & Individual-Level Predictors & Intercepts-As-Outcomes Model \\
\hline & & Level 1 & \\
\hline Intercept & $3.67^{*}\left(0.19^{*}\right)$ & $3.67^{*}\left(0.19^{*}\right)$ & $3.67^{*}\left(0.11^{*}\right)$ \\
PEV & & $0.49^{*}\left(0.21^{*}\right)$ & $0.49^{*}\left(0.21^{*}\right)$ \\
\hline & Control variables \\
\hline Gender & 0.03 & 0.03 \\
Age & $0.01 *$ \\
Education & -0.02 & $0.01^{*}$ \\
\hline & Cross level \\
\hline GOC & & -0.02 \\
Level-1 residual variance & 0.446 & 0.323 & $0.65^{*}$ \\
Model deviance & 1206.84 & 1046.28 & 0.321 \\
\hline
\end{tabular}

Note: $\mathrm{n}=587$ (employee); $\mathrm{n}=6$ (coal mine). Entries are estimates of the fixed effects $\left(\gamma_{\mathrm{s}}\right)$ with robust standard errors. Estimations of the random variance components $\left(\tau_{\mathrm{s}}\right)$ are in parentheses. The $\tau_{\mathrm{s}}$ for the intercepts also represent the between-mine variance in GOC. ${ }^{*} p<0.05$. Data source: collected by this research.

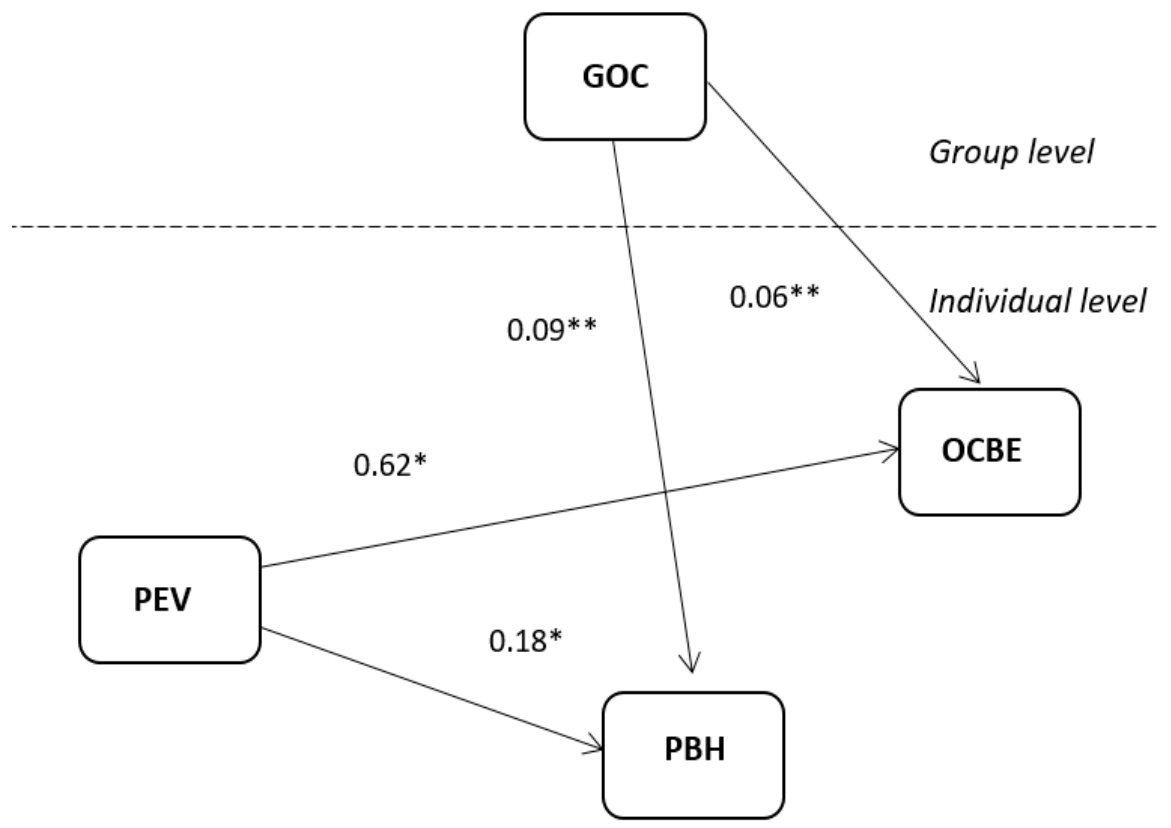

Figure 2. The estimated model. Data source: collected by this research. ${ }^{*} p<0.05 ;{ }^{* *} p<0.10$. 
Performing a one-way ANOVA, we found that the level of between-group variance for GOC was significant $(\mathrm{F}=15.48, p<0.01)$, meaning there was greater between-group variance relative to within-group variance. We measured the within-group agreement by calculating ICC $(1$; interclass correlation), ICC(2; inter-rater reliability), and $r_{w g}$, which provide a basis for aggregation to the group level. The ICC(1) value was 0.13 and significant $\left(\chi^{2}=11.01, p<0.001\right)$, suggesting that the between-group variance in the GOC measure was large [an ICC(1) value of 0.13 implies that $13 \%$ of the total variance in GOC was explained by coal mines, while $87 \%$ was explained by individual factors]. The ICC(2) value was 0.94 , which indicates strong inter-rater agreement $(>0.70)$. Similarly, the $r_{\mathrm{wg}}$ of 0.83 implies strong within-group agreement. The aggregation could thus be deemed appropriate.

\section{Results}

\subsection{Level-One Null Model}

Initially, we aimed to determine if a significant between-group variance in the independent variables was evident. Therefore, a null model with no independent level-one variables was estimated. To test the significance of the between-group variance, we calculated a chi-square $\left(\chi^{2}\right)$ statistic for both models. For the present study, the significant chi-square value for PBH was 47.398, meaning that one could potentially explain employee engagement in $\mathrm{PBH}$ by the percentage of the total between-group variance. The chi-square value for OCBE was 6517 but insignificant, meaning that employee engagement in OCBE could not be potentially explained by the percentage of the total between-group variance. The implication is that the coal mines that participated in the current study differed from each other only by way of employee engagement in PBH (if we take into account only the null model).

\subsection{Random Coefficient Regression Model}

We subsequently attempted to ascertain if a significant between-group variance in the intercepts (the intercept terms represent the between-group variance in the dependent variables after controlling for the independent variable) was evident. Thus, we estimated a random-coefficient regression model. In order to establish that the variance in the intercepts for the dependent variables (e.g., PBH and OCBE) across groups was significant, chi-square tests were conducted; if it transpired that there was not significant between-group variance, a group effect would not exist. The results subsequently indicate that there was significant between-group variance $\left(\chi^{2}=65.67, p<0.001\right)$ for PBH, and that there was significant between-group variance $\left(\chi^{2}=10.03, p=0.074\right)$ for OCBE, meaning that inserting the independent and the control variables (e.g., PEV, gender, age, and education) into the model differentiated the between-group variance in PBH and OCBE in the coal mines participating in the study.

A t-test was implemented to assess the significance of the mean of the coefficients across groups. This lent evidence to whether the pooled level-one slopes between the independent variables and the dependent variable diverged from zero. Thus, this test assessed whether there was significant relationships between PEV and PBH (H1) and between PEV and OCBE (H2) and, by implication, whether support was offered for both hypotheses. In fact, $\mathrm{H} 1(\mathrm{t}=5.11, p=0.004)$ and $\mathrm{H} 2$ were supported $(\mathrm{t}=6.98, p<0.001)$.

\subsection{Intercepts-As-Outcomes Model}

In order to test $\mathrm{H} 3$ and $\mathrm{H} 4$, the intercepts-as-outcomes model (see Figure 2) was estimated. The results present a significant effect of GOC on the dependent variables, thereby supporting both hypotheses (OCBE: $\mathrm{t}=2.57, p=0.062$ ) and (PBH: $\mathrm{t}=3.98, p=0.016$ ). It follows that a green organizational climate was found to positively affect employees' pro-environmental behaviors at home as well as their voluntary engagements in green action at work (although it was not very deep). In practice, this 
means that facet-specific climates (such as GOC) act normatively, encouraging individuals to behave in a certain way (discussed in more detail in Section 6).

\subsection{Climate Strength}

We also computed the strength of GOC by investigating the standard deviation of climate perceptions. It needs to be stressed that a small standard deviation characterizes the ratings that represent a climate that is unequivocal or strong. Accordingly, we confirmed that a value of the coefficient of variation lower than $20 \%$ was a threshold level determining a "higher" (or a "stronger"), as distinct from a "lower" (or a "weaker"), level of GOC. It turned out that, in two coal mines, there were strong climates; in the rest, climates were weak.

\section{Discussion}

\subsection{Theoretical Implications}

GOC was found to have a direct effect on both OCBE and PBH. Therefore, this study supports the cogency of the GOC construct, per se (see Figure 3). The within-group consensus demonstrates that GOC existed in each coal mine, although, as just mentioned, it was strong in only two of them (detailed more below). In this way, the present work contributes to climate scholarship (which pays relatively little attention to green organizational climates). These findings underline the significance of the workplace reality, which directly affects employee behavior at work and at home. Thus, our study adds substance to the view that (facet-specific) climates with positive overtones are, in essence, a normative influence [46]. Moreover, we showed that their impact went well beyond the workplace and extended - via the process of interiorization of values and, hence, conduct-to the home environment (or, in other words, an issue is a transposition of attitudinal and behavioral patterns from the workplace into a domestic context). All of which provides further proof of the validity of relevant theories (i.e., social information processing theory and organismic integration theory) while pointing to the role of external (contextual) factors in the motivation process. The implication is that (environmentally conscious) employers are well-positioned to advance the pursuit of sustainability in society at large.

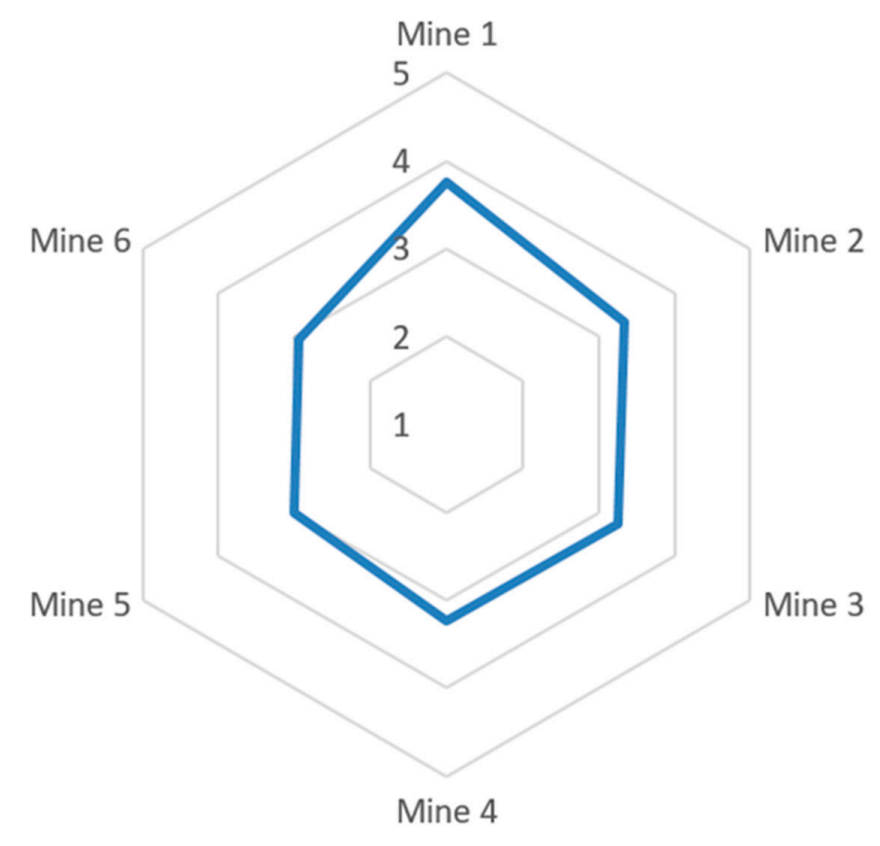

Figure 3. Average GOC for the six coalmines. Data source: collected by this research.

Furthermore, we discovered a significant relationship between environmental values and pro-environmental behavior. This is in line with previous studies (e.g., $[24,30,56])$ and lends additional 
credence to the cogency of the VNB theory. It is important to emphasize that we measured the PEV construct with such items as "I think it is necessary to shift from coal towards renewable sources of energy", which might have been interpreted by some respondents as provocative (given that the transition to renewables threatens coal miners' livelihood and is, from their individual points of view, hardly in their interest). This finding also constitutes a voice in the debate concerning the environmental values-behavior gap. It follows that the gap may be less prevalent than is commonly assumed. In other words, a person's attachment to green values need not be notional only and actually translates into pro-environmental conduct, which by itself is consistent with the view that values indeed "guide individuals to function in a society" [34] (p. 5). Given this and the fact that environmentally friendly behavior "can be regarded as a specific form of altruistic behavior" [21] (p. 143), the present work contributes to ethics literature, too.

Crucially, this finding coupled with evidence of the direct impacts of green organizational climates substantiates the claim - which, admittedly, is well-established in the literature- that it is a combination of both individual and organizational factors that undergird employee engagement in green behaviors. From a methodological viewpoint, the study, drawing on hierarchical level modeling, reinforces a rationale behind the use of the multilevel approach for investigating the problems regarding worker involvement in organizational greening.

\subsection{Practical Implications}

As regards ordinary Poles' stances on environmental protection, our findings present a nuanced picture. On the one hand, it is clear that coal miners, contrary to popular stereotypes portraying them as tough guys who do not care about sustainability, are not indifferent to the state of the environment (note that a small fraction of our sample was made up of women, that is, female administrative employees who do not work down the pit). They indeed hold environmental values and act accordingly. However, it has to be admitted that their actual engagement in voluntary pro-environmental action at work (as opposed to home) is not very deep (see Figure 4). That said, an important qualification needs to be remembered when interpreting this result; given the harsh reality of work in coal mines and the nature of any organizational citizenship behavior (e.g., it competes for a worker's time and attention with in-role tasks), it might be problematic to expect engagement in any sort of extra-role behavior to be very deep.

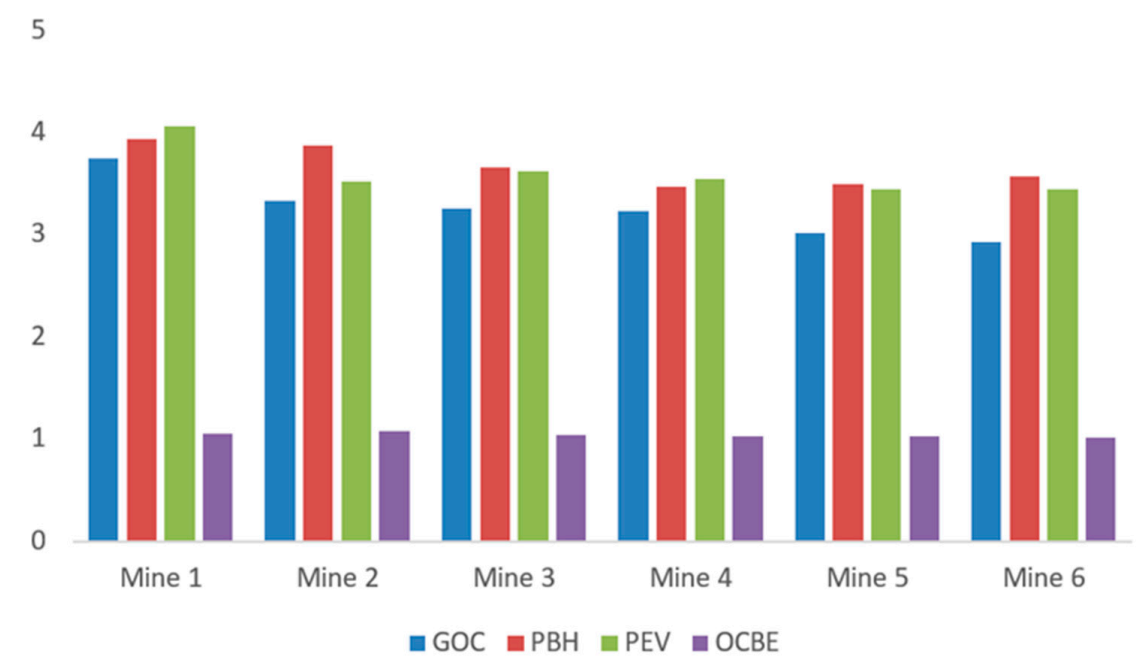

Figure 4. Average GOC, PBH, PEV, and OCBE for the six coal mines. Data source: collected by this research.

Furthermore, the existence of strong green organizational climates in two coal mines goes some way towards invalidating the claim that the industry does not engage in organizational greening and 
pays scant regard to environmental sustainability. Again, the above statement calls for an important qualification. The fact that GOC was weak in the other four coal mines participating in the study suggests that some Polish coal mines are more committed to organizational greening than others. From a certain point of view, this state of affairs is not hard to explain since, despite being owned by the state, coal mines in Silesia are autonomous and crucially differ from each other in terms of geological conditions and quality of coal (and, hence, profitability). In fact, the financial situation of the industry varies greatly, with some mines being structurally loss-making and some profitable or close to profitability (depending on the fluctuations of the price of coal in international markets). All this might, in turn, explain why some of them pay more attention to sustainability than others (e.g., the coal mines that are structurally unprofitable and cash-strapped probably show weak commitment) [57].

However, once more, the very existence of GOC, be it strong or weak, indicates that something is being done in the area of organizational greening - a conclusion that stands in contrast to what was going on within the industry in the first decade of the 21st century. In fact, at that time, it was unheard of for Polish coal mines to introduce green practices [58]. Yet, there is much more to this than that. Our results not only show that measures aimed at environmental protection are a reality in mines but also that, given how we operationalized GOC, managers (at least in the two mines with strong GOC) probably hold quite strong environmental beliefs, which also adds substance to the view that attitudes to nature in Poland are indeed shifting.

To recapitulate, our findings reinforce the case for intensification of green awareness-raising and environmental training provision both inside and outside the coal mining industry (e.g., in schools, institutions, government agencies, etc.). As is widely acknowledged, environmental training-in particular, interactive heuristic learning-is one of the main determinants of the formation of green organizational climates (participation with other co-workers in training sessions facilitates sharing experiences and, hence, collective sensemaking). Additionally, given the mechanism of interiorization of values and behavioral patterns, it is, by implication, one of the chief factors in the transposition of workplace experience into a home context. In other words, exposure to green climates at work as a result of environmental training provisions (and supervisor behavior) is likely to strengthen individual resolve to act responsibly outside the workplace. This is especially relevant in such countries as Poland, where a lot still needs to be done to improve the country's low standings in international environmental friendliness rankings.

\section{Conclusions}

Even though great strides have recently been made towards a low-carbon economy, coal is likely to remain an important energy source. Yet, coal mining is not held up as a paragon of organizational greening, and miners are not regarded as particularly attached to environmental values. The present study, by providing empirical evidence to the contrary, goes some way towards debunking these stereotypes (even though, to repeat, coal miners' engagement in pro-environmental behavior at work was not very deep). It has done so by means of a methodological approach that is rarely used in this line of research. In this way, it expands prior theorizing regarding mechanisms that underlie individual pro-environmental behavior by highlighting the role of group (organizational) influences. In fact, the present paper provides an argument in favor of the view that exploration of factors that determine individual pro-environmental behavior requires a multilevel (rather than single-level) approach. This is because most people belong to a social group and an organization (as employees or members), which, as we have shown, does influence their attitudes and behavior. Such a conceptualization reflects the view that the very nature of ethical behavior and the environmentally responsible behaviors that are perceived as such is inherently nested; workers/consumers are nested in organizations, which are nested in industries, which themselves are nested in societies. Given this, the present paper-which, to reiterate, draws on data from an industry and a society that have thus far had a reputation for environmentally unfriendliness—-has important ethical overtones. 
However, this research work is not devoid of certain limitations, which should be acknowledged and which pave the way for future research opportunities. Firstly, a relatively small sample and self-reports were relied upon, meaning that caution is in order when generalizing the findings. Secondly, the study was both cross-sectional and correlational in nature, thereby identifying correlations rather than causation. Accordingly, there is a need for a longitudinal design. Another issue concerns our approach. In fact, we did not ask managers about whether or how their coal mines go about organizational greening. Rather, we drew on individual perceptions of low-ranking employees aggregated to the group level. The advantage of such an approach is that workers completing questionnaires are more sincere than managers who, when interviewed, tend to portray their organizations in a positive light. That said, low-ranking employees may not be fully aware of all the environmental measures taken by their employer. Thus, interviews with managers coupled with content analysis of sustainability reports might potentially offer a full picture of the situation.

Author Contributions: Conceptualization, P.Z., G.M. and A.M.N.-W.; Methodology, A.Z. and P.Z.; Software, A.Z.; Validation, A.Z. and P.Z.; Formal analysis, P.Z. and G.M.; Curation, A.Z. and P.Z.; Writing-original draft preparation, P.Z. and A.Z.; Writing-review and editing, P.Z., A.M.N.-W. and G.M.; Supervision, P.Z., A.Z. and A.M.N.-W.; Project administration P.Z. and A.M.N.-W.

Funding: This research received no external funding.

Conflicts of Interest: The authors declare no conflict of interest.

\section{Appendix A}

Table A1. The research instrument.

\begin{tabular}{|c|c|c|c|c|c|c|}
\hline No. & List of the Items & $\begin{array}{c}1 \\
\text { Strongly } \\
\text { Disagree }\end{array}$ & 2 & 3 & 4 & $\begin{array}{c}5 \\
\text { Strongly } \\
\text { Agree }\end{array}$ \\
\hline 1 & $\begin{array}{l}\text { I spontaneously give my time to help my colleagues take the } \\
\text { environment into account in everything they do at work. }\end{array}$ & & & & & \\
\hline 2 & At home I try to reduce the use of water and energy. & & & & & \\
\hline 3 & I pay attention to the eco-friendliness of domestic appliances. & & & & & \\
\hline 4 & $\begin{array}{l}\text { I encourage my colleagues to adopt more environmentally conscious } \\
\text { behavior. }\end{array}$ & & & & & \\
\hline 5 & I actively participate in environmental events organized by my company. & & & & & \\
\hline 6 & My company provides me with ecological training. & & & & & \\
\hline 7 & I commute to work by public transport. & & & & & \\
\hline 8 & I feel supported by my supervisor in my green activities. & & & & & \\
\hline 9 & $\begin{array}{l}\text { I believe that environmental protection is one of the most important } \\
\text { issues in the 21st century. }\end{array}$ & & & & & \\
\hline 10 & My company has an environmental policy in place. & & & & & \\
\hline 11 & $\begin{array}{l}\text { I am encouraged by my supervisor to actively engage in } \\
\text { pro-environmental behavior. }\end{array}$ & & & & & \\
\hline 12 & My company stresses the need to use fewer chemicals. & & & & & \\
\hline 13 & Climate change is a problem that needs to be effectively tackled. & & & & & \\
\hline 14 & My supervisor inspires me to act in an environmentally responsible way. & & & & & \\
\hline 15 & I believe that environmentally harmful behavior is morally wrong. & & & & & \\
\hline 16 & At home I segregate waste for recycling. & & & & & \\
\hline 17 & $\begin{array}{l}\text { In my work, I weigh the consequences of my actions before doing } \\
\text { something that could affect the environment. }\end{array}$ & & & & & \\
\hline 18 & Humans are severely abusing the environment. & & & & & \\
\hline 19 & I feel deeply attached to environmental protection. & & & & & \\
\hline 20 & My company implements practices aimed at resource efficiency. & & & & & \\
\hline 21 & I opt for holiday destinations that are not far away so as to avoid flying. & & & & & \\
\hline 22 & In my work, waste management is a common practice. & & & & & \\
\hline 23 & $\begin{array}{c}\text { I think it is necessary to shift from coal towards renewable sources of } \\
\text { energy. }\end{array}$ & & & & & \\
\hline
\end{tabular}




\section{References}

1. Nikodemska-Wolowik, A.M. (Ed.) Polish and Swedish SME's towards CSR Challenges; Responsible Business Forum and Pomerania Development Agency: Kalmar Lan, Sweden; Warsaw, Poland, 2011.

2. Ulewicz, R.; Blaskova, M. Sustainable Development and Knowledge Management from the Stakeholders' Point of View. Pol. J. Manag. Stud. 2018, 18, 363-374. [CrossRef]

3. Environmental Performance Index (EPI). 2018 EPI Results. Available online: https://epi.envirocenter.yale. edu/epi-topline?country=Poland (accessed on 21 March 2019).

4. Barr, S. Factors influencing environmental attitudes and behaviors. A U.K. case study of household waste management. Environ. Behav. 2007, 39, 435-473. [CrossRef]

5. Kollmuss, A.; Agyeman, J. Mind the gap: Why do people act environmentally and what are the barriers to pro-environmental behavior? Environ. Educ. Res. 2002, 8, 239-260. [CrossRef]

6. Simmons, J.; Widmar, R. Motivations and barriers to recycling. Toward a strategy for public education. J. Environ. Educ. 1990, 22, 13-18. [CrossRef]

7. Steg, L.; Vlek, C. Encouraging pro-environmental behavior: An integrative review and research agenda. J. Environ. Psychol. 2009, 29, 309-317. [CrossRef]

8. Thøgersen, J. The motivational roots of norms for environmentally responsible behavior. Basic Appl. Soc. Psychol. 2009, 31, 348-362. [CrossRef]

9. Thøgersen, J.; Ölander, F. Spillover of environment-friendly consumer behavior. J. Environ. Psychol. 2003, 23, 225-236. [CrossRef]

10. Vining, J.; Ebreo, A. Predicting recycling behavior from global and specific environmental attitudes and changes in recycling opportunities. J. Appl. Soc. Psychol. 1992, 22, 1580-1607. [CrossRef]

11. Wiidegren, Ö. The new environmental paradigm and personal norms. Environ. Behav. 1998, 30, 75-100. [CrossRef]

12. Miao, L.; Wei, W. Consumers' pro-environmental behavior and its determinants in the lodging segment. J. Hosp. Tour. Res. 2016, 40, 319-338. [CrossRef]

13. Bissing-Olson, M.J.; Iyer, A.; Fielding, K.S.; Zacher, H. Relationships between daily affect and pro-environmental behavior at work: The moderating role of pro-environmental attitude. J. Organ. Behav. 2013, 34, 156-175. [CrossRef]

14. Daily, B.F.; Bishop, J.W.; Govindarajulu, N. A conceptual model for organizational citizenship behavior directed toward the environment. Bus. Soc. 2009, 48, 243-256. [CrossRef]

15. Lamm, E.; Tosti-Kharas, J.; King, C.E. Empowering employee sustainability: Perceived organizational support toward the environment. J. Bus. Ethics 2015, 128, 207-220. [CrossRef]

16. Paillé, P.; Mejía-Morelos, J.H.; Marché-Paillé, A.; Chen, C.C.; Chen, Y. Corporate greening, exchange process among co-workers, and ethics of care: An empirical study on the determinants of pro-environmental behaviors at co-workers level. J. Bus. Ethics 2016, 136, 655-673. [CrossRef]

17. Raineri, N.; Paillé, P. Linking corporate policy and supervisory support with environmental citizenship behaviors: The role of employee environmental beliefs and commitment. J. Bus. Ethics 2016, 137, 129-148. [CrossRef]

18. Kennedy, E.H.; Beckley, T.M.; McFarlane, B.L.; Nadeau, S. Why we don't "walk the talk": Understanding the environmental values/behavior gap in Canada. Hum. Ecol. Rev. 2009, 16, 151-160.

19. Maciejewski, G. The Contemporary Consumer in the Face of Megatrends in Consumption (Chapter 2). In The Transformation of Consumption and Consumer Behaviour; Olejniczuk-Merta, A., Ed.; IBRKK: Warsaw, Poland, 2012; pp. 27-42.

20. Leslie, D. Tourism, tourists and sustainability. In Tourism Enterprises and the Sustainability Agenda across Europe; Leslie, D., Ed.; Ashgate: Farnham, UK, 2012; pp. 15-34.

21. Onwezen, M.C.; Antonides, G.; Bartels, J. The Norm Activation Model: An exploration of the functions of anticipated pride and guilt in pro-environmental behavior. J. Econ. Psychol. 2013, 39, 141-153. [CrossRef]

22. Maciejewski, G.; Mokrysz, S.; Wróblewski, Ł. Segmentation of Coffee Consumers Using Sustainable Values: Cluster Analysis on the Polish Coffee Market. Sustainability 2019, 11, 613. [CrossRef]

23. Arvola, A.; Vassallo, M.; Dean, M.; Lampila, P.; Saba, A.; Lähteenmäki, L. Predicting intentions to purchase organic food: The role of affective and moral attitudes in the theory of planned behavior. Appetite 2008, 50, 443-454. [CrossRef] 
24. Oreg, S.; Katz-Gerro, T. Predicting proenvironmental behavior cross-nationally: Values, the theory of planned behavior, and value-belief-norm theory. Environ. Behav. 2006, 38, 462-483. [CrossRef]

25. Stern, P.C.; Dietz, T.; Abel, T.; Guagnano, G.A.; Kalof, L. A Value-Belief-Norm Theory of Support for Social Movements: The Case of Environmentalism. Hum. Ecol. Rev. 1999, 6, 81-97.

26. Schwartz, S.H. Normative influence on altruism. In Advances in Experimental Social Psychology; Berkowitz, L., Ed.; Academic Press: New York, NY, USA, 1977; pp. 221-279.

27. Gursoy, D.; Chi, C.G.; Karadag, E. Generational differences in work values and attitudes among frontline and service contact employees. Int. J. Hosp. Manag. 2013, 32, 40-48. [CrossRef]

28. Schminke, M.; Arnaud, A.; Taylor, R. Ethics, values, and organizational justice: Individuals, organizations, and beyond. J. Bus. Ethics 2015, 130, 727-736. [CrossRef]

29. Jang, Y.J.; Kim, W.G.; Lee, H.Y. Coffee shop consumers' emotional attachment and loyalty to green stores: The moderating role of green consciousness. Int. J. Hosp. Manag. 2015, 44, 146-156. [CrossRef]

30. Lamm, E.; Tosti-Kharas, J.; Williams, E.G. Read this article, but don't print it: Organizational citizenship behavior toward the environment. Group Organ. Manag. 2013, 38, 163-197. [CrossRef]

31. Andersson, L.; Shivarajan, S.; Blau, G. Enacting ecological sustainability in the MNC: A test of an adapted value-belief-norm framework. J. Bus. Ethics 2005, 59, 295-305. [CrossRef]

32. Nooney, J.G.; Woodrum, E.; Hoban, T.J.; Clifford, W.B. Environmental worldview and behavior consequences of dimensionality in a survey of North Carolinians. Environ. Behav. 2003, 35, 763-783. [CrossRef]

33. Festinger, L. A Theory of Cognitive Dissonance; Stanford University Press: Stanford, CA, USA, 1957.

34. Rokeach, M. The Nature of Human Values; Free Press: New York, NY, USA, 1973.

35. Smith, A.M.; O'Sullivan, T. Environmentally responsible behavior in the workplace: An internal social marketing approach. J. Mark. Manag. 2012, 28, 469-493. [CrossRef]

36. Borial, O.; Paille, P.; Raineri, N. The Nature of Employees Pro-Environ Behaviors. In The Psychology of Green Organizations; Robertson, J.L., Barling, J., Eds.; Oxford University Press: Oxford, UK, 2015.

37. Mirvis, P. Employee engagement and CSR: Transactional, relational, and developmental approaches. Calif. Manag. Rev. 2012, 54, 93-117. [CrossRef]

38. Deci, E.L.; Ryan, R.M. Intrinsic Motivation and Self-Determination in Human Behavior; Plenum: New York, NY, USA, 1985.

39. Elango, B.; Paul, K.; Kundu, S.K.; Paudel, S.K. Organizational ethics, individual ethics, and ethical intentions in international decision-making. J. Bus. Ethics 2010, 97, 543-561. [CrossRef]

40. Scholtens, B.; Dam, L. Cultural values and international differences in business ethics. J. Bus. Ethics 2007, 75, 273-284. [CrossRef]

41. Ryan, R.M.; Deci, E.L. Self-determination theory and the facilitation of intrinsic motivation, social development, and well-being. Am. Psychol. 2000, 55, 68-78. [CrossRef] [PubMed]

42. Bandura, A. Social Learning and Personality Development; Holt, Rinehart and Winston: New York, NY, USA, 1963.

43. Ellemers, N.; Haslam, S.A. Social identity theory. In Handbook of Theories of Social Psychology; Van Lange, P.A.M., Kruglanski, A.W., Higgins, E.T., Eds.; Sage: Thousand Oaks, CA, USA, 2012; pp. 379-398.

44. Salancik, G.J.; Pfeffer, J. A social information processing approach to job attitudes and task design. Adm. Sci. Q. 1978, 23, 224-253. [CrossRef] [PubMed]

45. Schneider, B.; Reichers, A. On the etiology of climates. Pers. Psychol. 1983, 36, 19-41. [CrossRef]

46. Kuenzi, M.; Schminke, M. Assembling fragments into a lens: A review, critique, and proposed research agenda for the organizational work climate literature. J. Manag. 2009, 35, 634-717. [CrossRef]

47. Zientara, P.; Zamojska, A. Green organizational climates and employee pro-environmental behavior in the hotel industry. J. Sustain. Tour. 2018, 26, 1142-1159. [CrossRef]

48. Cantor, D.E.; Morrow, P.C.; Montabon, F. Engagement in environmental behaviors among supply chain management employees: An organizational support theoretical perspective. J. Supply Chain Manag. 2012, 48, 33-51. [CrossRef]

49. Konovsky, M.A.; Pugh, D.S. Citizenship behavior and social exchange. Acad. Manag. J. 1994, 37, 656-669.

50. Deci, E.L.; Eghrari, H.; Patrick, B.C.; Leone, D.R. Facilitating internalization: The self-determination theory perspective. J. Personal. 1994, 62, 119-142. [CrossRef] 
51. TNS Polska. Badanie świadomości i zachowań ekologicznych mieszkańców Polski [A Study on Poles' Environmental Awareness and Eco-Friendly Behaviors]. Available online: www.mos.gov.pl/g2/big/2014_12/ fe749deb7e1414bf1c4afbc6548300f9.pdf/ (accessed on 31 August 2016).

52. Boiral, O.; Paillé, P. Organizational Citizenship Behaviour for the Environment: Measurement and Validation. J. Bus. Ethics 2012, 109, 431-445. [CrossRef]

53. Hair, J.F.; Black, W.C.; Babin, B.J.; Anderson, R.E.; Tatham, R.L. Multivariate Data Analysis; Pearson Prentice Hall: Upper Saddle River, NJ, USA, 2010.

54. Chan, D. Functional relations among constructs in the same content domain at different levels of analysis: A typology of composition models. J. Appl. Psychol. 1998, 83, 234-246. [CrossRef]

55. Baron, R.M.; Kenny, D. The Moderator-Mediator Variable Distinction in Social Psychological Research: Conceptual, Strategic, and Statistical Considerations. J. Personal. Soc. Psychol. 1986, 51, 1173-1182. [CrossRef]

56. Rajiani, I.; Pypłacz, P. National culture as modality in managing the carbon economy in southeast Asia. Pol. J. Manag. Stud. 2018, 18, 296-310. [CrossRef]

57. Zientara, P. Polish government policy for coal (1989-2006). Int. J. Energy Sect. Manag. 2007, 1, $273-294$. [CrossRef]

58. Zientara, P. Coal mining, economic development and environmental sustainability: A case of Poland. J. Energy Dev. 2007, 32, 189-206.

(C) 2019 by the authors. Licensee MDPI, Basel, Switzerland. This article is an open access article distributed under the terms and conditions of the Creative Commons Attribution (CC BY) license (http://creativecommons.org/licenses/by/4.0/). 